\title{
IMPLEMENTATION OF '5S' TECHNIQUE IN A MANUFACTURING ORGANIZATION: A CASE STUDY
}

\author{
Shraddha P. Deshpande ${ }^{1}$, Vipul V. Damle ${ }^{2}$, Merang L. Patel ${ }^{3}$, Akshay B. Kholamkar ${ }^{4}$ \\ ${ }^{1}$ Assistant Professor, Mechanical Engineering Department, GES'S R H. Sapat College of Engineering, Nasik, \\ Maharashtra, India \\ ${ }^{2}$ B. E. Mech.(student), Mechanical Engineering Department, GES's R H. Sapat College Of Engineering, Nasik, \\ Maharashtra, India \\ ${ }^{3}$ B. E. Mech.(student), Mechanical Engineering Department, GES's R H. Sapat College Of Engineering ,Nasik, \\ Maharashtra, India \\ ${ }^{4}$ B. E. Mech.(student), Mechanical Engineering Department, GES's R H. Sapat College Of Engineering ,Nasik, \\ Maharashtra, India
}

\begin{abstract}
The paper represents an application of ' $5 S$ ' technology in one of the MNC Samsonite South Asia Pvt. Ltd., Gonde-Dumala, Maharashtra which is the leading manufacturer of the luggage bags in the world. ' $5 S$ ' in simple terms is a Japanese technique consisting of five 'S' terms namely Seiri (sorting), Seiton (set in order), Seiso (shine), Seiketsu (standardize) and Shitsuke (sustain) having a deep sense for managing the work place. The aim of the implementation of ' $5 S$ ' in the organization is to enhance the productivity, safety, efficiency through effective workplace management. The need for the implementation of '5S' in the organization came into existence due to unorganized work-stations, uncomfortable working environment and the excessive wastes in the company. Hence to get rid-off of the above factors, there was an urgent need for the successive implementation of '5S' in the organization. The effective following on ' $5 S$ ' in the organization by the various official staff and workman's strengthens the work ethic between them resulting in the motivation towards teamwork. The successive implementation of ' $5 S$ ' transformed the organization drastically, right from the working conditions to the employees working satisfaction.
\end{abstract}

Keywords: 5S, Workplace Management

\section{INTRODUCTION}

Every organization aims for profit. In today's global market of decreasing profit margins, the profit made from the waste as well as through proper workplace management is mandatory. Thus it is directly related to the competition of the particular organization with the competitor. Hence the profit from the waste and through the proper workplace management can be made only when there will be a stringent implementation of some workplace management technique and that technique is ' $5 \mathrm{~S}$ ' concept.

Also the Samsonite South Asia, Gonde aims for building it to a world-class level organization. Thus organization adopted the concept of ' $5 \mathrm{~S}$ ' for enhancing the profit, class of the company, working conditions, etc. and implemented the ' $5 \mathrm{~S}$ ' technique successfully. Also the organization have various departments such as assembly, stores, injection moulding, maintenance and tool room, administration where the implementation of ' $5 \mathrm{~S}$ ' would result in a huge enhancement in productivity, proper workplace condition, increased profits and motivation to employees.

\subsection{What Is '5S'?}

' $5 \mathrm{~S}$ ' is one of the Japanese techniques which was introduced by Takashi Osada in the early 1980s [8]. It is basically a workplace management methodology which helps for improving working environment, human capabilities and thereby productivity [8]. The word ' $5 \mathrm{~S}$ ' represents the 5 discipline for maintaining visual workplace. ' $5 \mathrm{~S}$ ' is workplace management to minimize the loss of time and unnecessary movements as well. It comprises 5 principles in making the organization highly efficient and effective those are:-

Seiri: - (sorting)

1. Perform sorting activity at your workplace i.e. into wanted and unwanted things.

2. Remove all the unwanted things that are at your workplace.

3. Only keep those things that you need.

Seiton: - (set in order)

1. Decide place for everything that you need.

2. Give proper identification to it for ease of search.

3. Keep everything at its defined place after use.

4. Make sure every time that everything is at its place.

Seiso: - (shine)

1. Always keep cleanliness at your workplace.

2. Keep the tools always clean after its use.

3. Areas should be properly marked or painted. 
Seiketsu: - (standardize)

1. Define standard method/way of doing the work i.e. prepare standard operating procedure (SOP).

2. Do the work in that method/way only.

3. Maintain the discipline in your work [5].

Shitsuke: - (sustain)

1. Maintain consistency in the method of doing work [3].

2. Stick to the ' $5 \mathrm{~S}$ ' rules for proper workplace management.

3. Encourage the participation of all, for consistency in ' $5 \mathrm{~S}$ ' activities.

4. Perform ' $5 \mathrm{~S}$ ' activities periodically.

\subsection{Organization Introduction}

Samsonite South Asia Pvt. Ltd., Nasik (India) inaugurated in 1998. The luggage industry started with metal luggage and then with soft luggage. In last two decades plastic luggage by Samsonite became popular due to their various excellent properties. Plastic luggage can be made by plastic injection moulding and sheet forming.

Samsonite group is specialized in all travel solutions and making all the products related to the journey. The products are manufacture at various locations depending upon the availability of skilled labours and logistics benefit.

\section{PROBLEM STATEMENT}

The following problems occurred before implementation of ' $5 \mathrm{~S}$ ' in the organization:

1. Improper utilization of storage space for raw material, bins and finished products.

2. Wastage of time in searching the raw material due to non-permanent location for storage of raw material.

3. Low productivity due to the time wastage in searching for tools, materials due to improper workplace management.

4. Presence of unwanted materials at the workplace which affects the moral of the worker while working.

5. Useful storage space being acquired by the unwanted materials.

6. More time and cost required for the inventory process of unwanted stored materials in raw material stores.

7. No well defined space for storing the unwanted or rejected material.

8. Unequal participation of officers and workers in workplace management due to non standardization.

\section{METHODOLOGY}

The following method was adopted to implement ' $5 \mathrm{~S}$ ':

1. To create awareness among the employees for the implementation of ' $5 \mathrm{~S}$ ', various awareness programs and presentations were undertaken by the various experts in the organization. Also the official staff visited the leading organization's in which ' $5 \mathrm{~S}$ ' had already being implemented successfully.
2. As the organization consist of various departments it was difficult and impossible to imply directly the ' $5 \mathrm{~S}$ ' technique in the organization. Hence the organization was simplified into various zones consisting of specific departments along with it, the zone leaders and sub-zone leaders were also appointed. The organization was simplified as:

Table -1: Simplification of Organization

\begin{tabular}{|c|c|}
\hline ZONE & SUB-ZONES \\
\hline \multirow{4}{*}{ 1.Periphery } & 1.Parking \& Main Gate \\
\hline & 2.Gate House \\
\hline & 3.Garden \& Periphery Road \\
\hline & 4.IMD Pantry \\
\hline \multirow{2}{*}{$\begin{array}{l}\text { 2.Old Admin/New } \\
\text { Admin }\end{array}$} & 1.Old Admin \\
\hline & 2. New Admin \\
\hline \multirow{4}{*}{$\begin{array}{l}\text { 3.Bonded Store } \\
\text { Room (BSR) / } \\
\text { Raw Material } \\
\text { (RM) Stores }\end{array}$} & 1.BSR \\
\hline & 2.RM Stores \\
\hline & 3.Old RM Stores \\
\hline & 4.Carton Storage Area \\
\hline \multirow{4}{*}{ 4.Main Assembly } & 1.Poly-Propelene \& Curve Line \\
\hline & 2.Curve Line \\
\hline & 3.Quality Audit (QA) \\
\hline & 4.Basement 1 \\
\hline \multirow{17}{*}{$\begin{array}{l}\text { 5.Injection } \\
\text { Moulding } \\
\text { Department (IMD) }\end{array}$} & 1. $1200 \mathrm{~T}$ A Machine \\
\hline & 2. $1200 \mathrm{~T}$ B Machine \\
\hline & 3. $400 \mathrm{~T}$ Machine \\
\hline & 4. ILLIG-A Machine \\
\hline & 5. ILLIG-B Machine \\
\hline & 6. U200 Machine \\
\hline & 7. Welex Machine \\
\hline & 8. Amut Machine \\
\hline & 9. Laser Machine \\
\hline & 10. Press Former A Machine \\
\hline & 11. Press Former B Machine \\
\hline & 12. Press Former C Machine \\
\hline & 13. Router \& Drilling Machine \\
\hline & 14. Re-Grinder R1 \\
\hline & 15. Re-Grinder R2 \\
\hline & 16. Re-Grinder R3 \\
\hline & 17. IMD Office \& Shell \\
\hline \multirow{4}{*}{$\begin{array}{l}\text { 6. Tool Room \& } \\
\text { Maintenance }\end{array}$} & $\begin{array}{l}\text { 1. Low Tension (LT) Room, } \\
\text { Diesel Generator(DG) Room \& } \\
\text { Substation }\end{array}$ \\
\hline & $\begin{array}{l}\text { 2.Cooling Towers \& Pump } \\
\text { House }\end{array}$ \\
\hline & 3.IMD Chillers \\
\hline & 4.Extruder Chiller \\
\hline
\end{tabular}




\begin{tabular}{|c|c|}
\hline & 5.Maintenance Area \\
\hline & 6.IMD Panels \\
\hline & 7.Assembly/Office Panels \\
\hline & 8.Pressure Forming Panels \\
\hline & 9.Frame/Soft Panels \\
\hline & 10.Lathe Machine \\
\hline & 11.Milling Machine \\
\hline & 12.Spoting Machine \\
\hline & 13.Grinding Machine \\
\hline & $\begin{array}{l}\text { 14.Cutting Machine \& Raw } \\
\text { Material }\end{array}$ \\
\hline & 15.Working Area \\
\hline & 16.Basket Repair \\
\hline & 17.Tool Room Basement \\
\hline & 18.Oil Yard \\
\hline \multirow{7}{*}{ 7. Development } & $\begin{array}{l}\text { 1.Development Model Shop \& } \\
\text { Front Passage }\end{array}$ \\
\hline & $\begin{array}{l}\text { 2. Development Office, Meeting } \\
\text { Room, Sample Room }\end{array}$ \\
\hline & 3.Softside Model Shop \& Store \\
\hline & 4.Inward QA \& Sorting Area \\
\hline & 5.RM Store \& Rejection Area \\
\hline & $\begin{array}{l}\text { 6. Development Basement } \\
\text { Assembly Line }\end{array}$ \\
\hline & 7.Canteen \\
\hline
\end{tabular}

3. Now as the organization was simplified into different zones, the ' $1 \mathrm{~S}$ ' activity was undertaken by the respective zones under the guidance of respective zone leaders.

4. After the implementation of ' $1 \mathrm{~S}$ ' in various zones, the audit was conducted by the apex team of the organization. Then the queries raised from the audit by the apex team were taken into consideration by the respective zones and the corrective measures were taken on it.

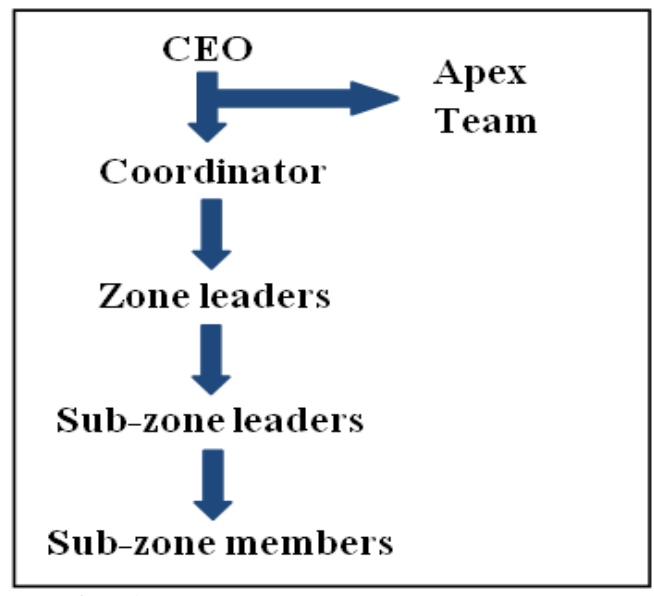

Fig -1: Organization structure
5. After that, the presentation session was conducted on ' $1 \mathrm{~S}$ ' for the whole staff along with the workers and at last, the best three zones were awarded based on the performance of respective zones.

6. Similarly the rest ' $4 S$ ' were implemented one after the other successfully.

\section{ACTUAL IMPLIMENTATION OF '5S' IN THE SIMPLIFIED ZONES}

\subsection{Seiri (Sorting-1S)}

Sorting aims for removing all the unwanted materials from the workplace. After sorting the unwanted materials from the workplace, they are placed in the red tag area and the details of it are noted down on the red tag card (as shown in Fig -2). The materials noted down on the red tag card are then moved to scrap yard or located properly or rectified or segregated or returned to the supplier based on the decision of apex team and zone leader [3].

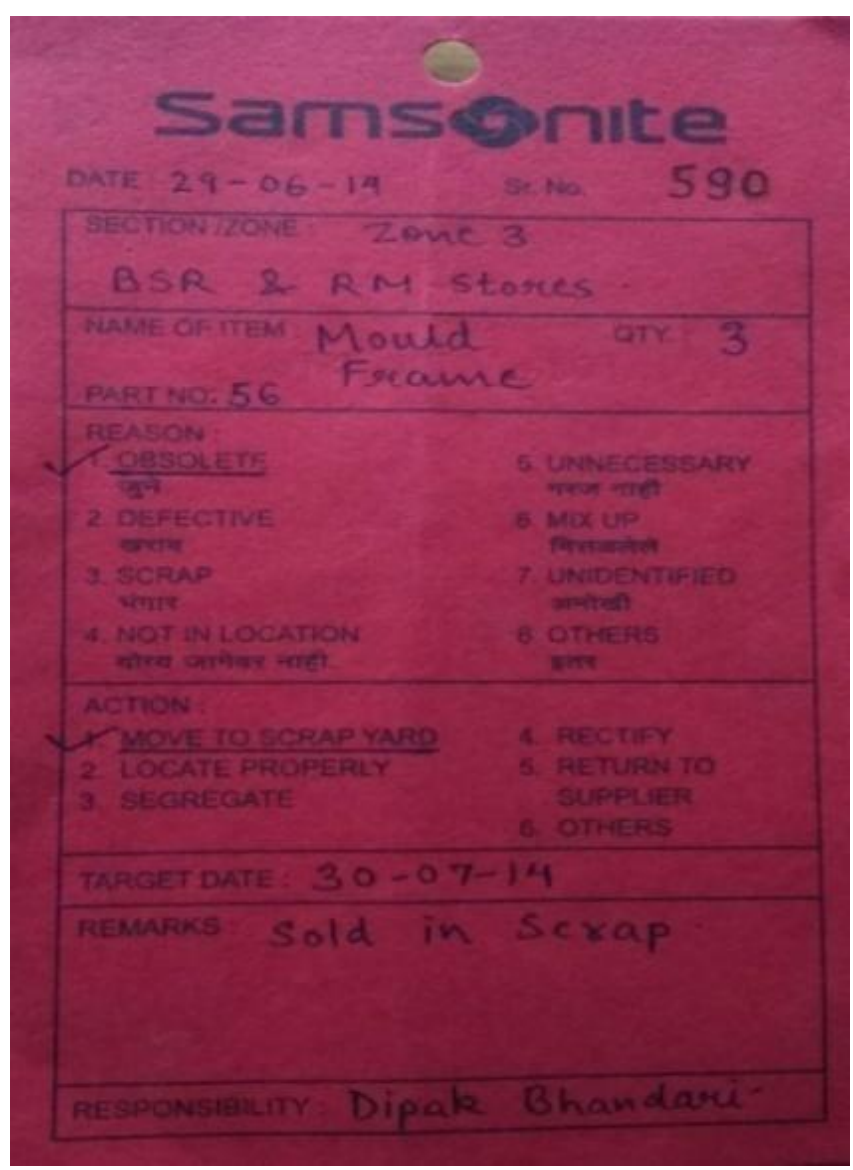

Fig -2: Red tag card 


\subsubsection{Injection Moulding Department (Zone 5):}
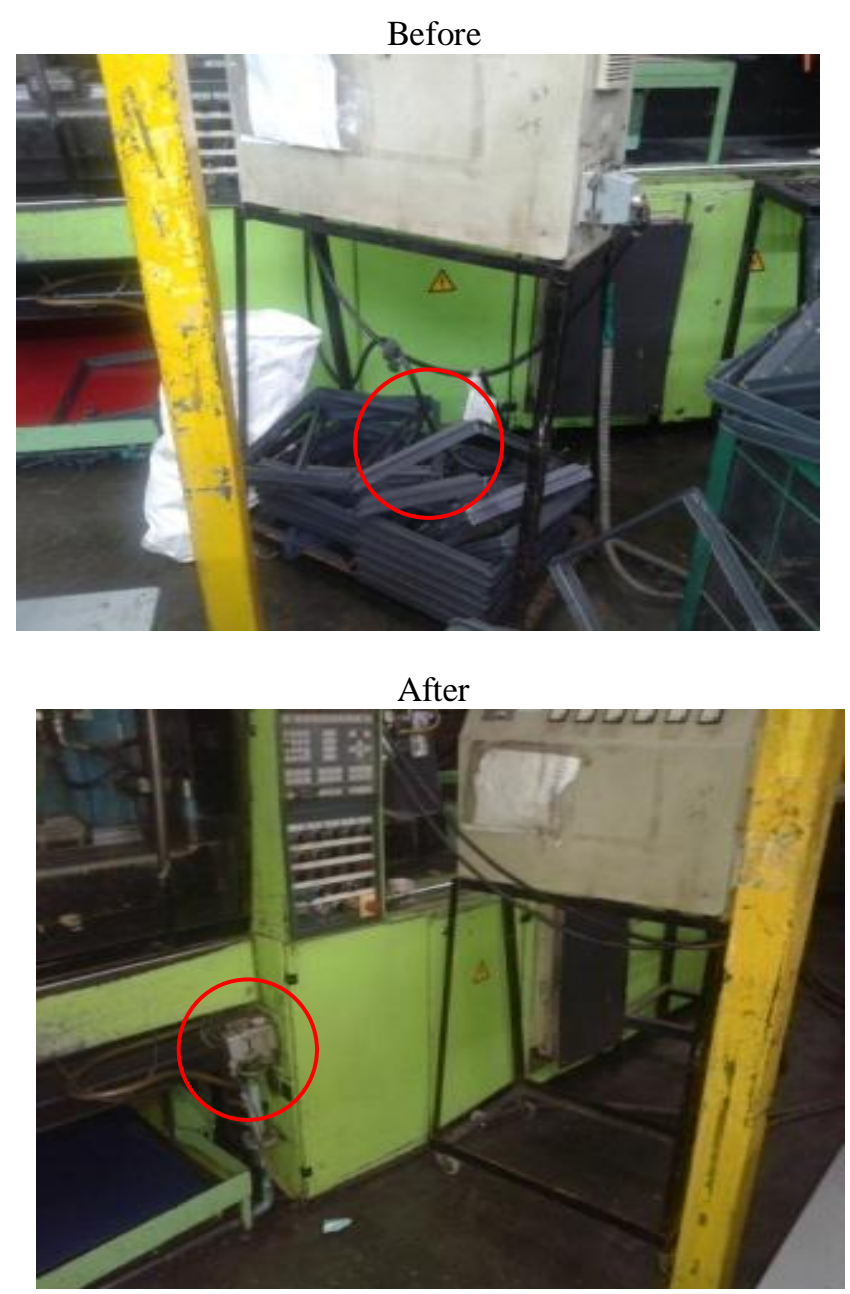

Fig -3: Injection moulding 400T machine area

Unwanted frames placed below the electrical panel are removed.

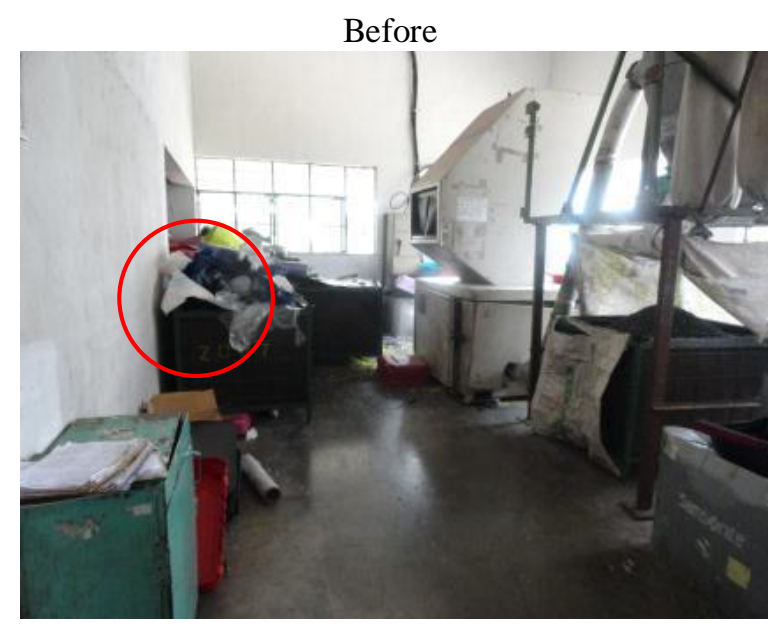

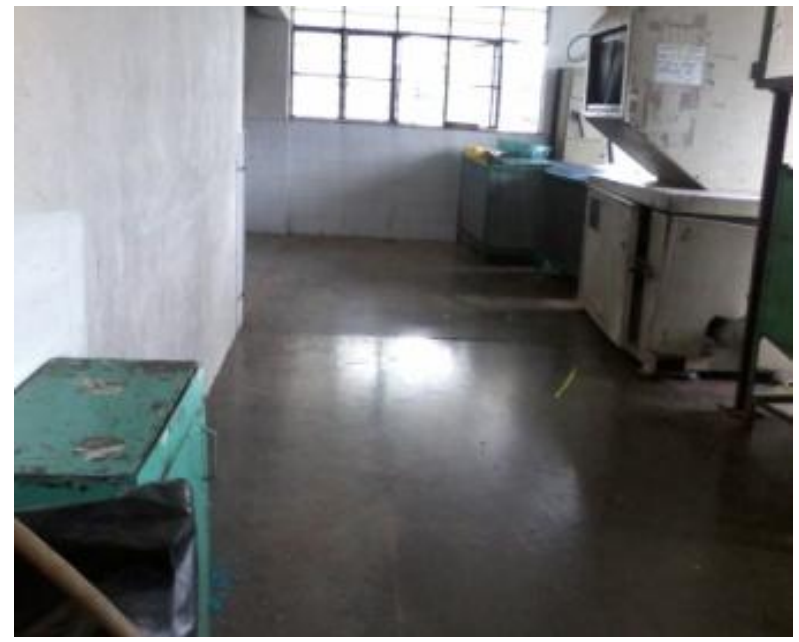

Fig -4: Grinding room

Rejected shells are removed.
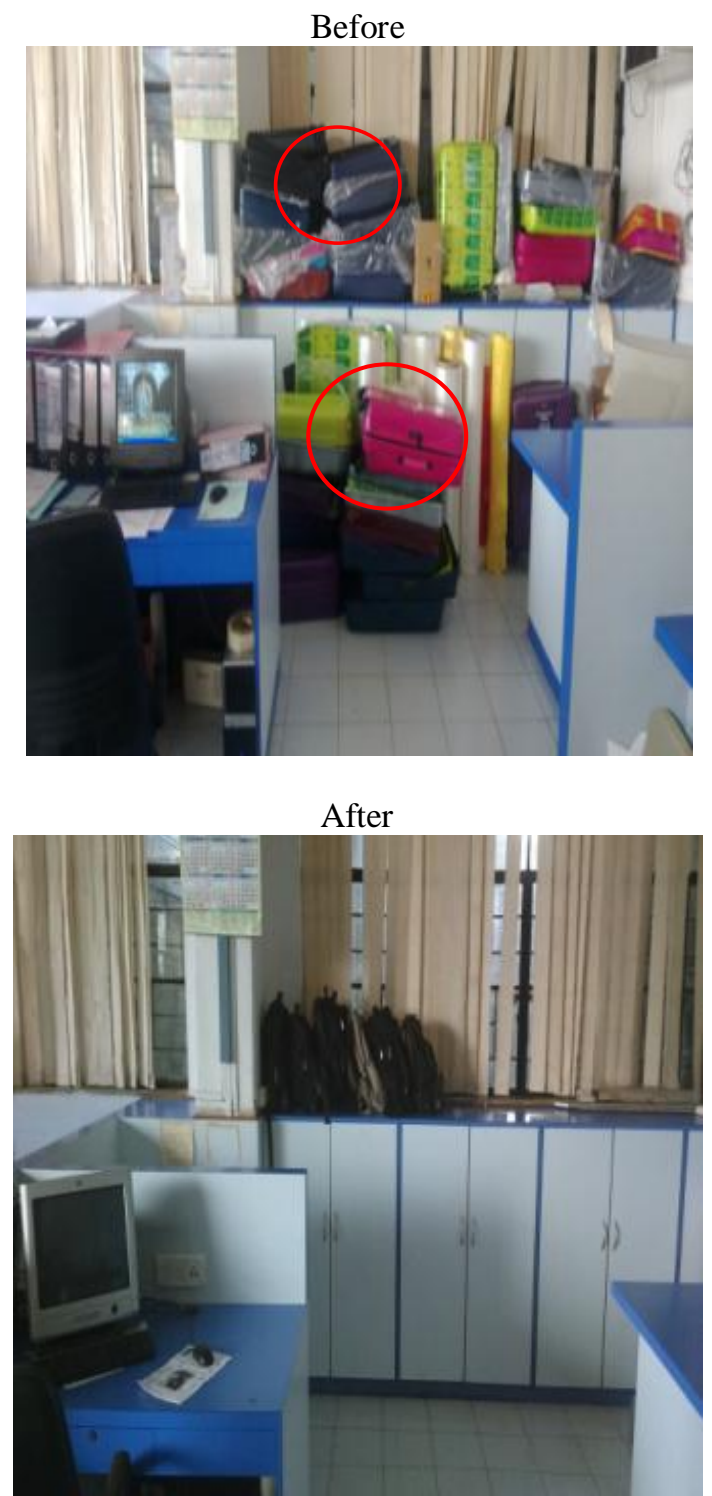

Fig -5: Injection moulding dept. office

Lots of usable and unusable material acquiring office area 


\subsubsection{Tool Room \& Maintenance (Zone 6):}
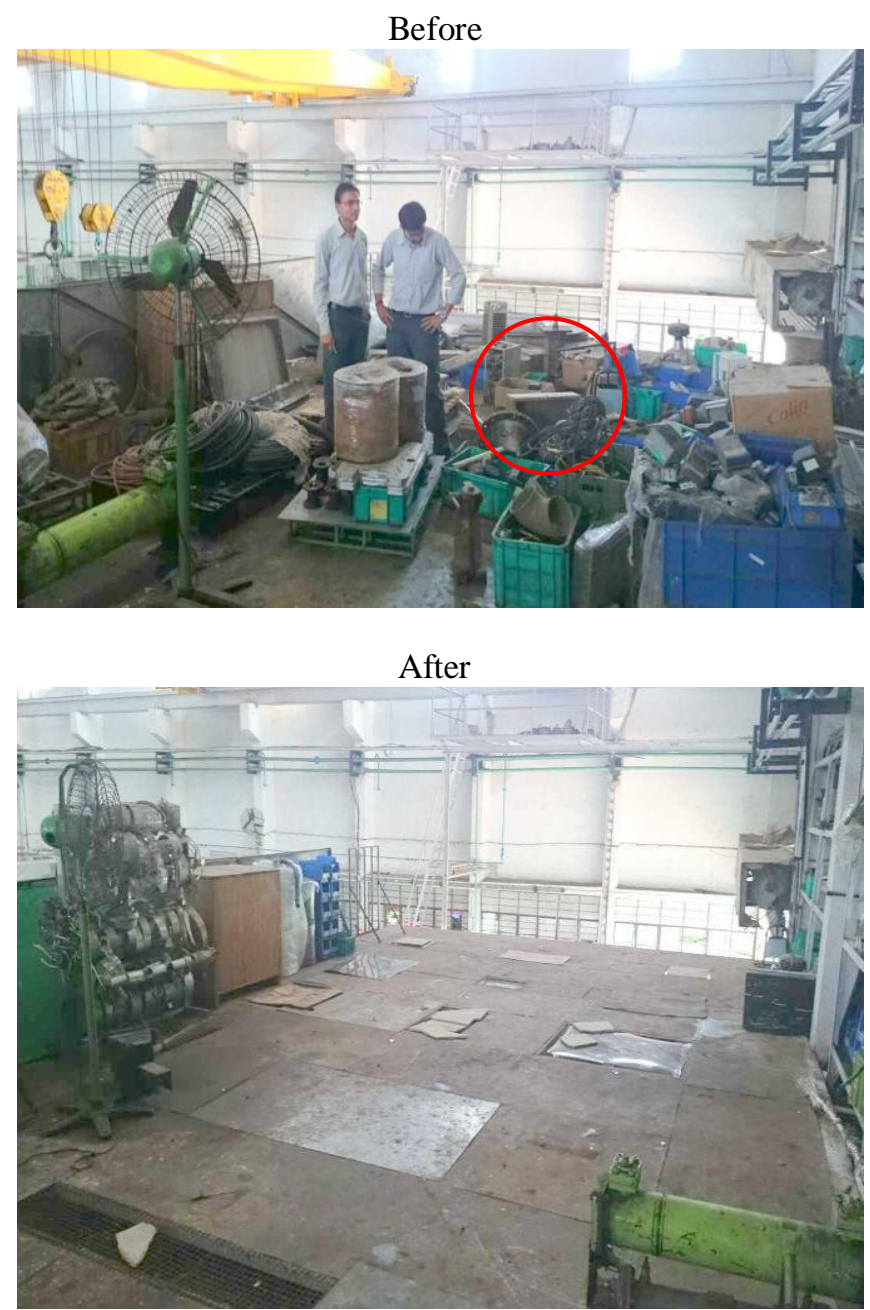

Fig -5: Tool room area

All the machine parts and material sorted and unwanted parts moved to scrap yard.

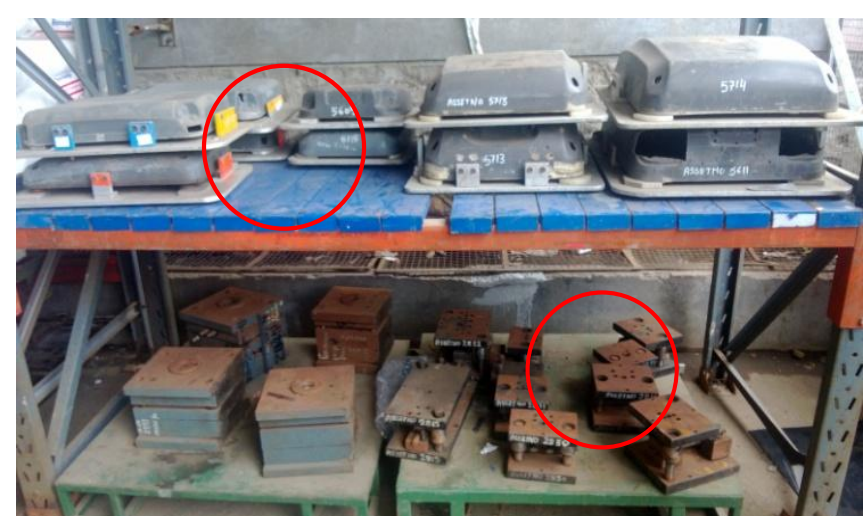

Fig -6: Rack

Rack space being acquired by unusable fixtures and dies.

\subsubsection{Main Assembly (Zone 4):}
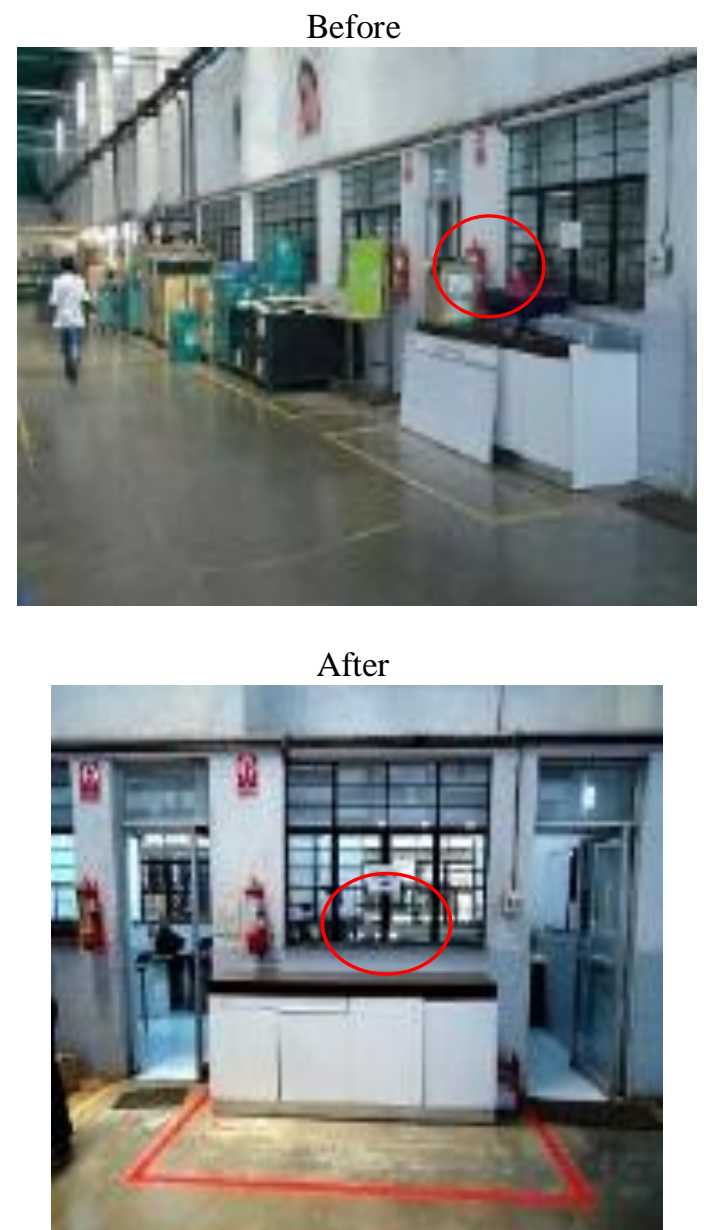

Fig -7: Outside of assembly office

The unwanted material placed on table in the passage way is replaced by the red tag area.

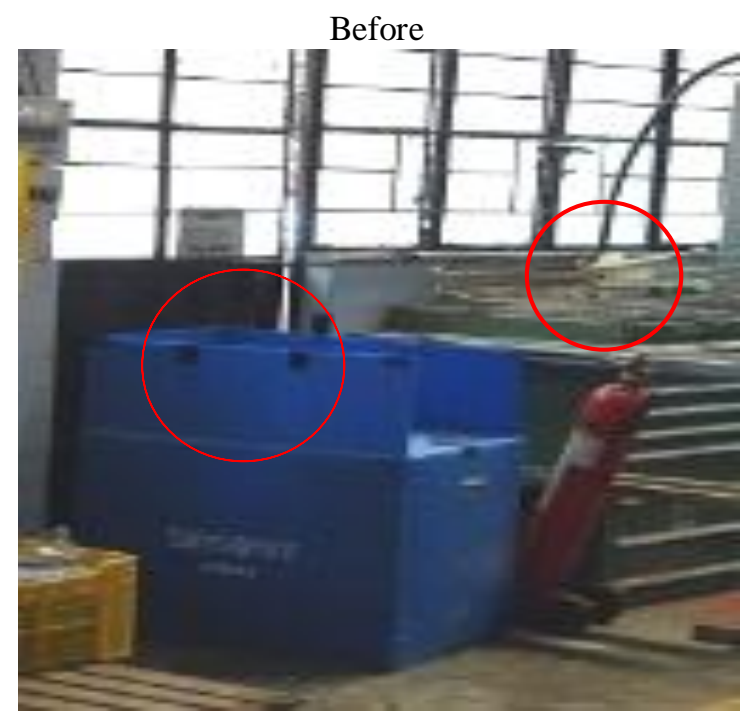




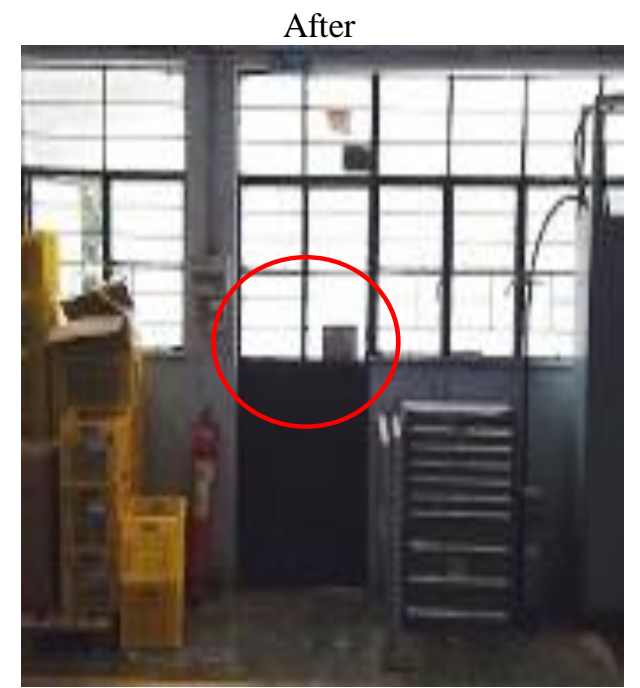

Fig -8: Emergency door

Emergency door way covered by the shell carton.
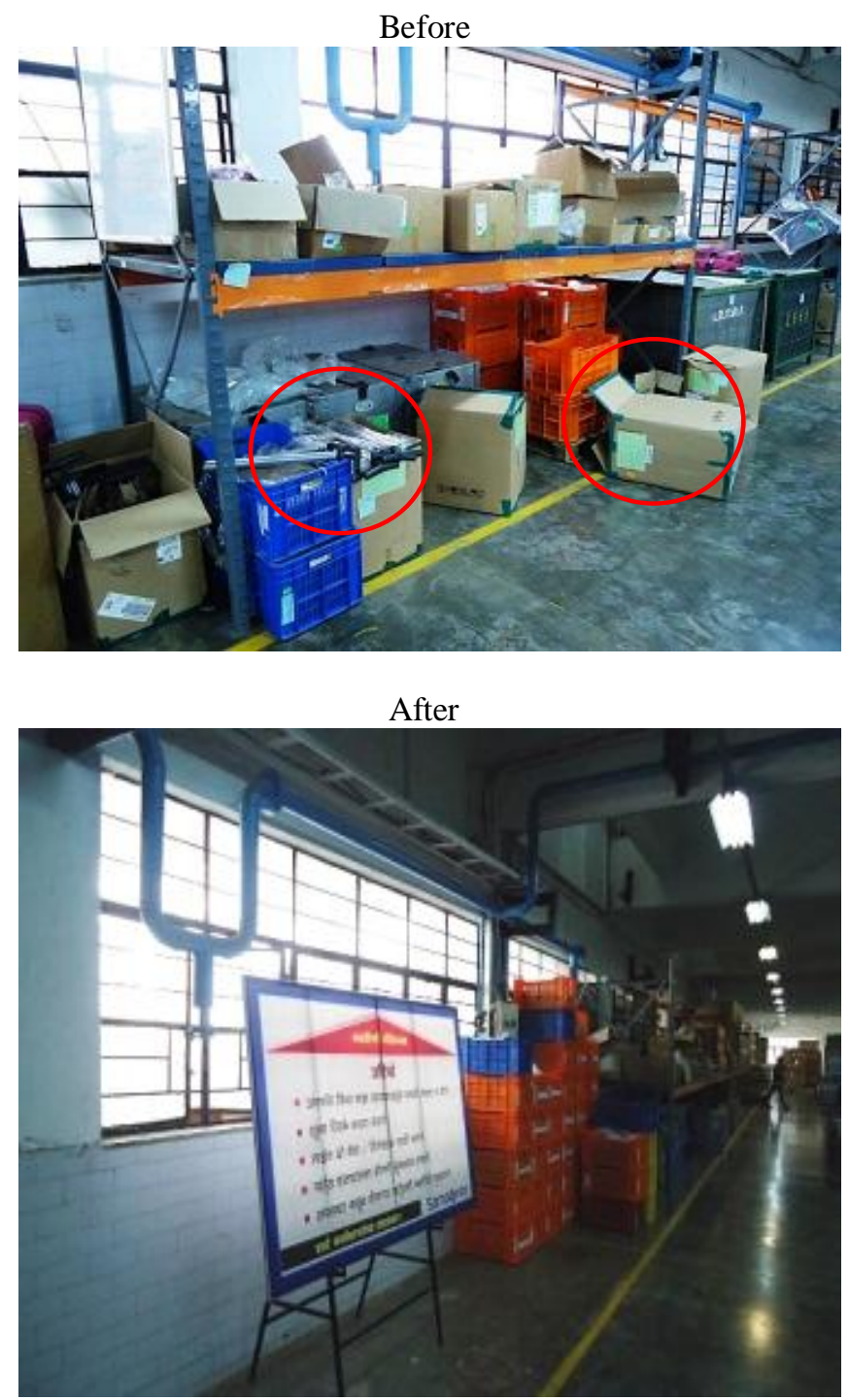

Fig -9: Empty passage of assembly
All the materials that occupied the passage way is sorted and moved to scrap yard which provided cleared passage way.

\subsubsection{BSR/RM Stores (Zone 3):}
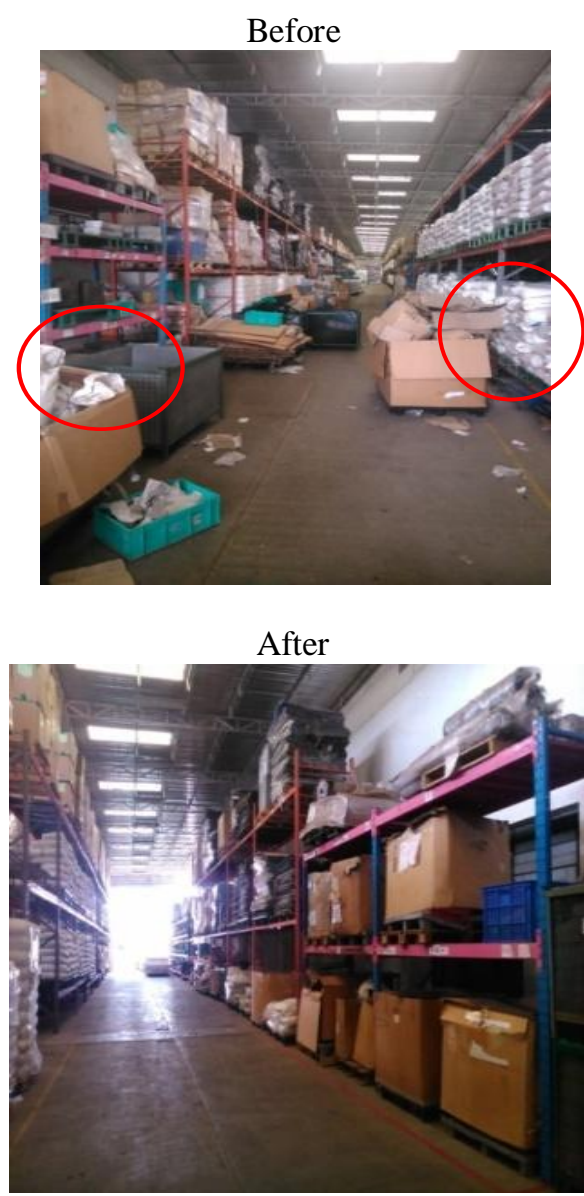

Fig -10: Gangway of RM stores

Material in the passage of gangway is sorted properly which provided well defined gangway.

\subsection{Seiton (Set In Order-2S):}

Set in order aims at "place for everything and everything in its place" [2]. After sorting, the specific location is defined for the useful material and located in the predefined order.

\subsubsection{Injection Moulding Department (Zone 5):}

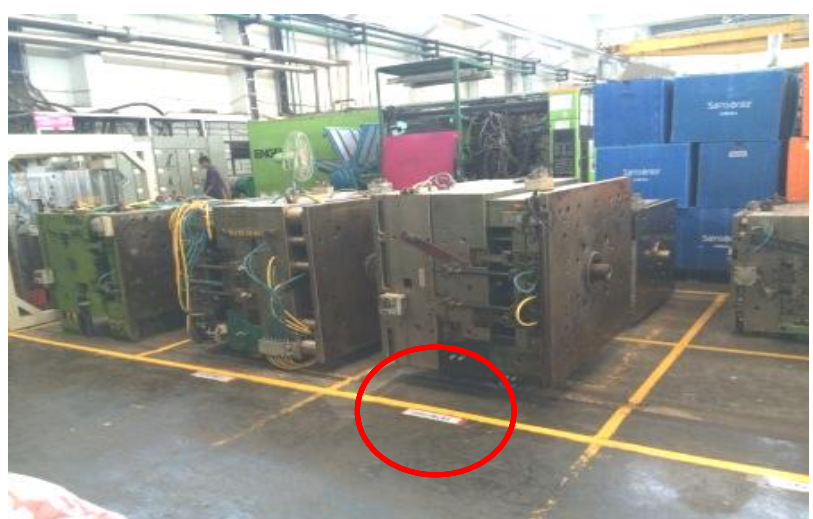

Fig -11: Proper place for moulds 
Injection moulds stored properly in allocated area with proper labeling.

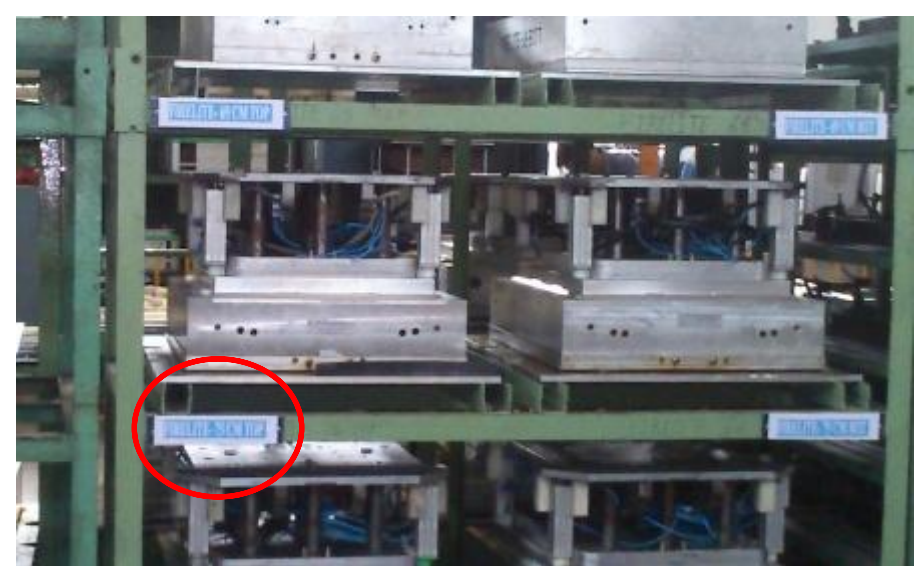

Fig -12: Vacuum and pressure forming moulds rack

Pressure vacuum forming moulds stored properly in allocated rack with proper labeling.

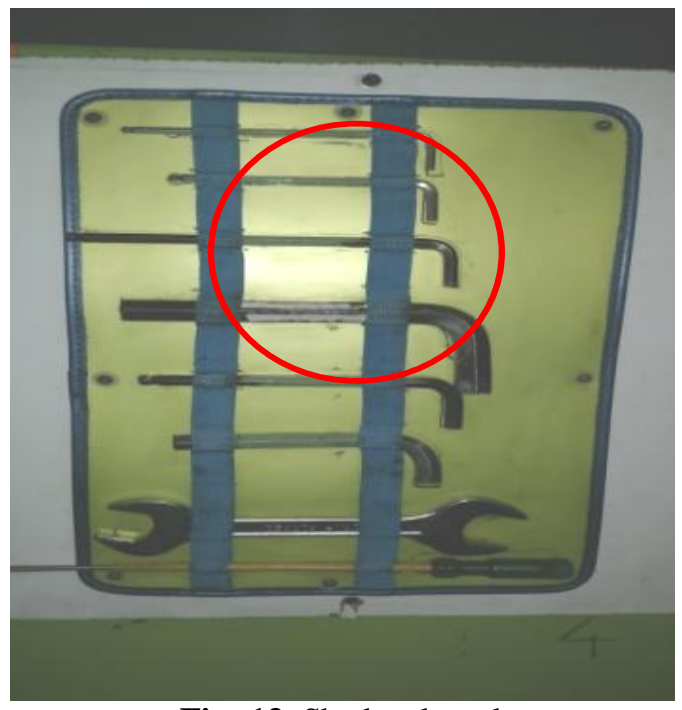

Fig -13: Shadow board

Shadow boards for hand tools prepared by the zone members from the rejected poly-propylene sheets which made them easily visible.

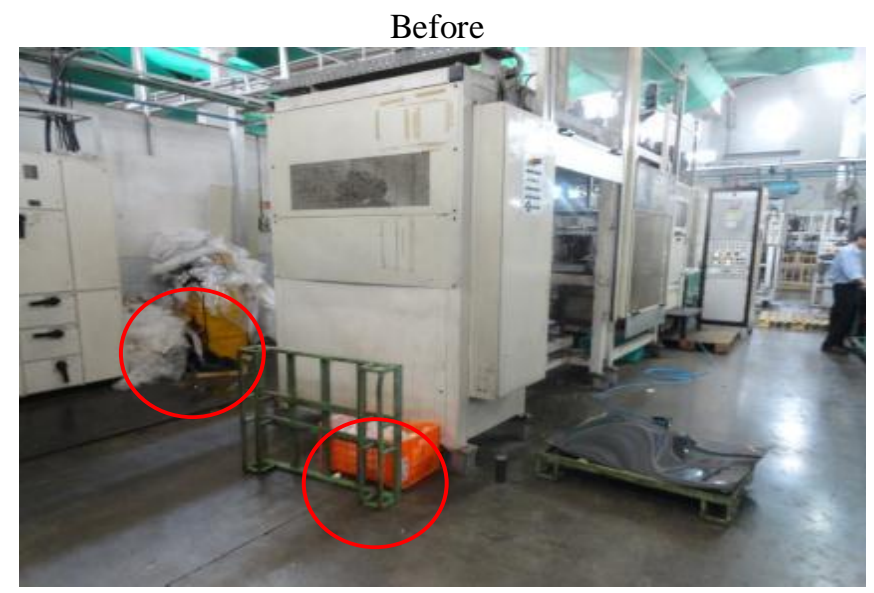

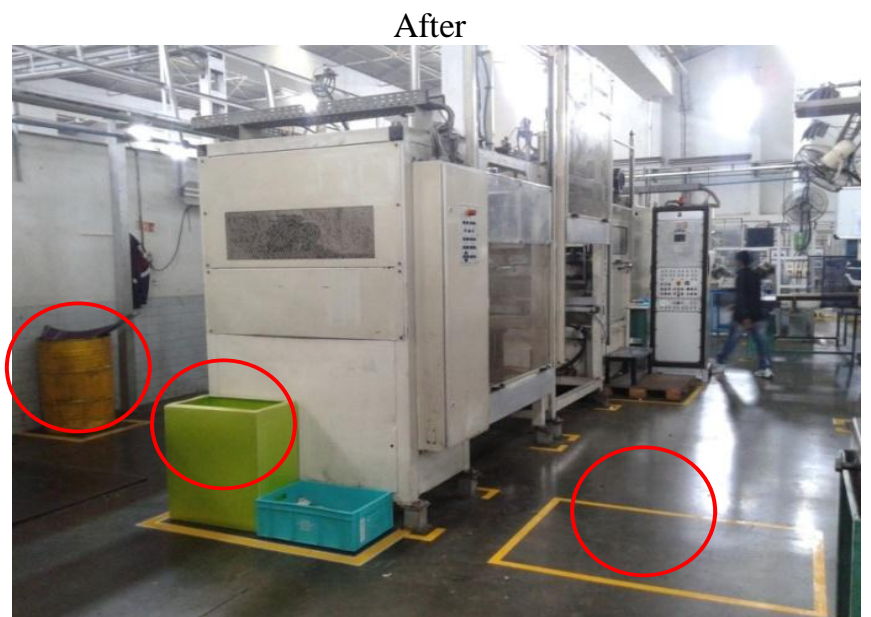

Fig -14: Vacuum forming machine area

Proper location and identity defined to dustbin, first piece sample and sheets required for shell production.
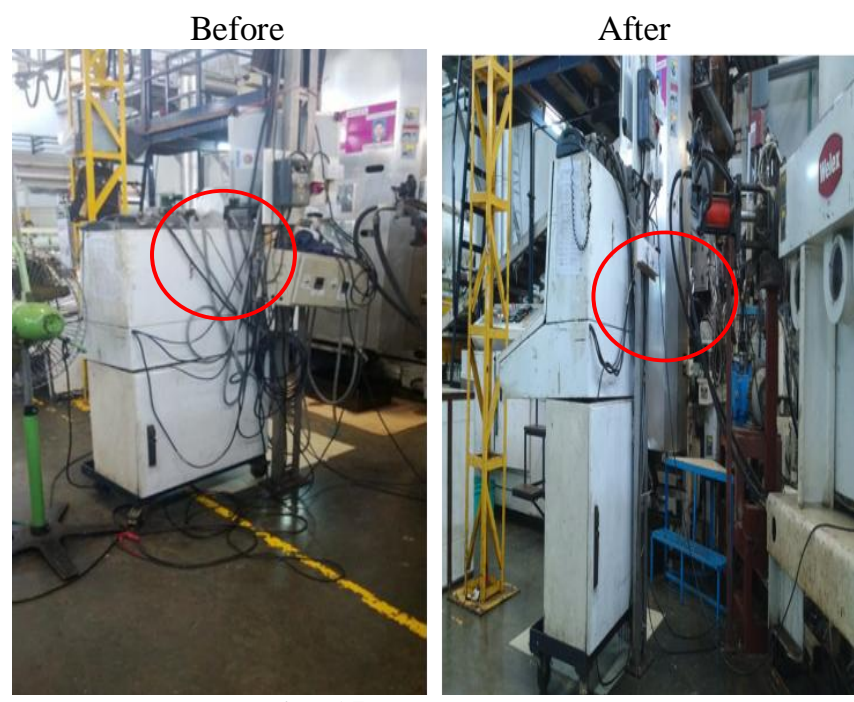

Fig -15: Welex machine

Proper wiring of machine is done.

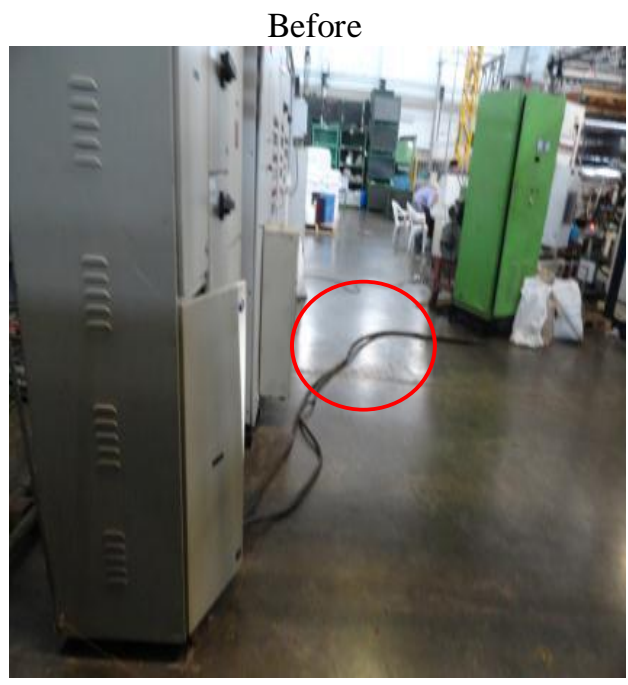




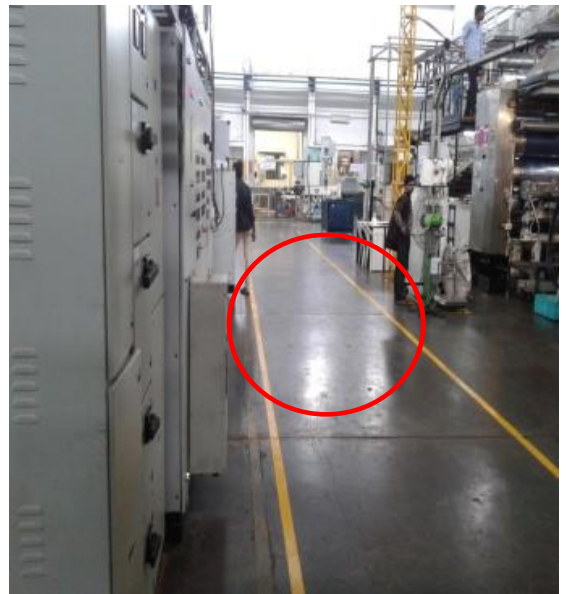

Fig -16: Welex machine area

Well defined gangway.

\subsubsection{Tool Room \& Maintenance (Zone 6):}

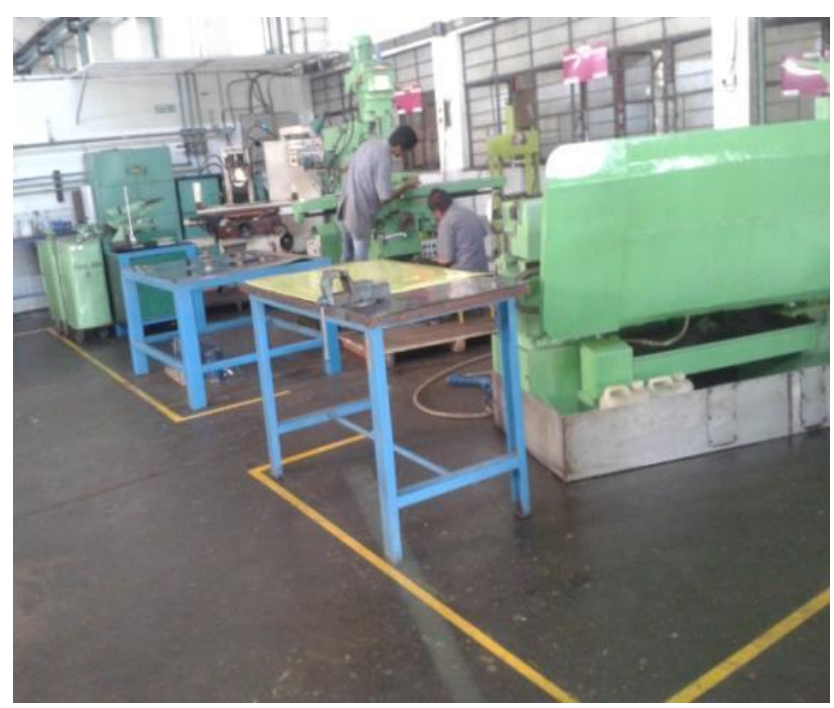

Fig -18: Tool room \& maintenance machine area

Proper space is allotted for lathe, milling and grinding machine.

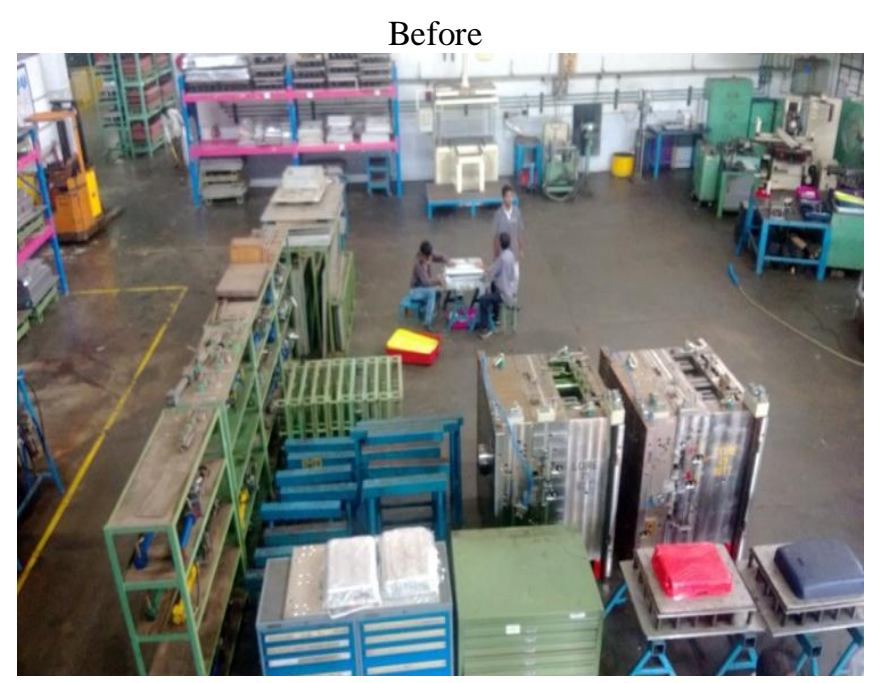

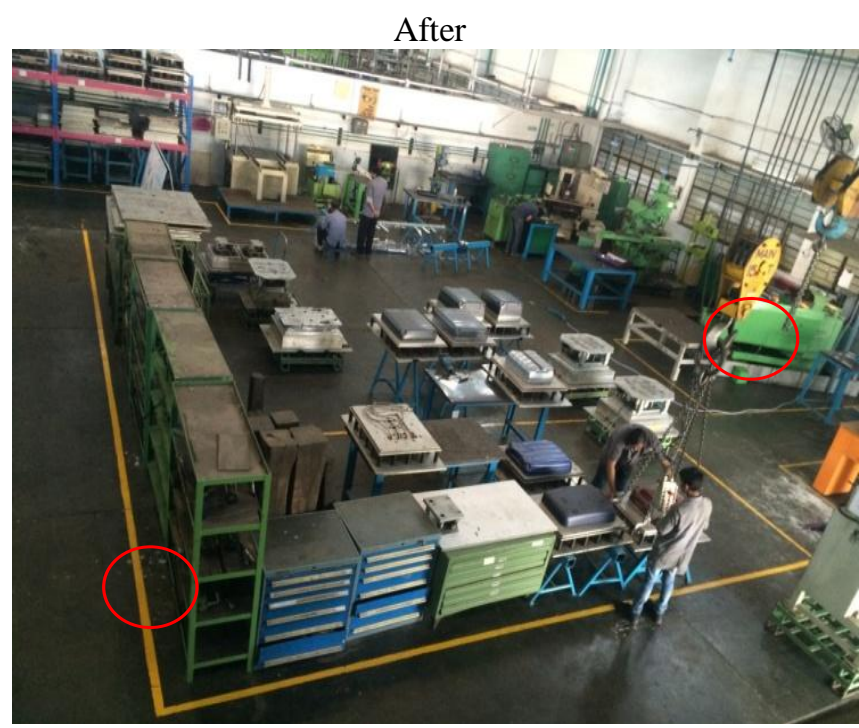

Fig -17: Tool room \& maintenance dept.

Proper location and space defined for racks, mould area, machines.

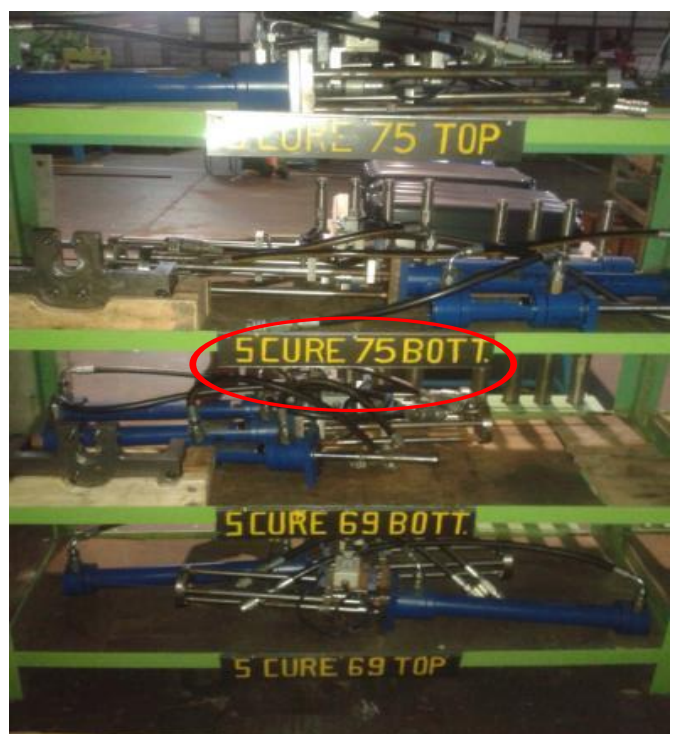

Fig -20: Rack for parts under maintenance

Proper place and identification defined to the machine parts under maintenance.

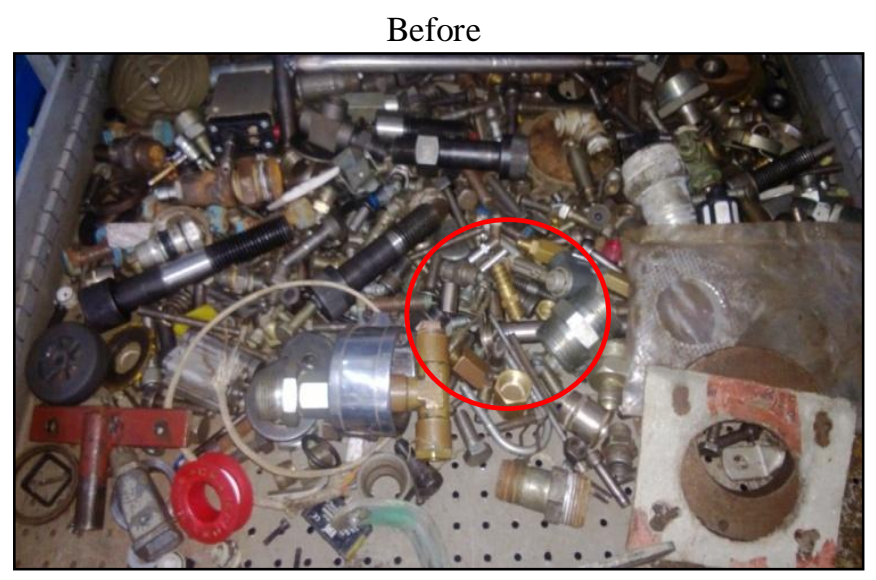




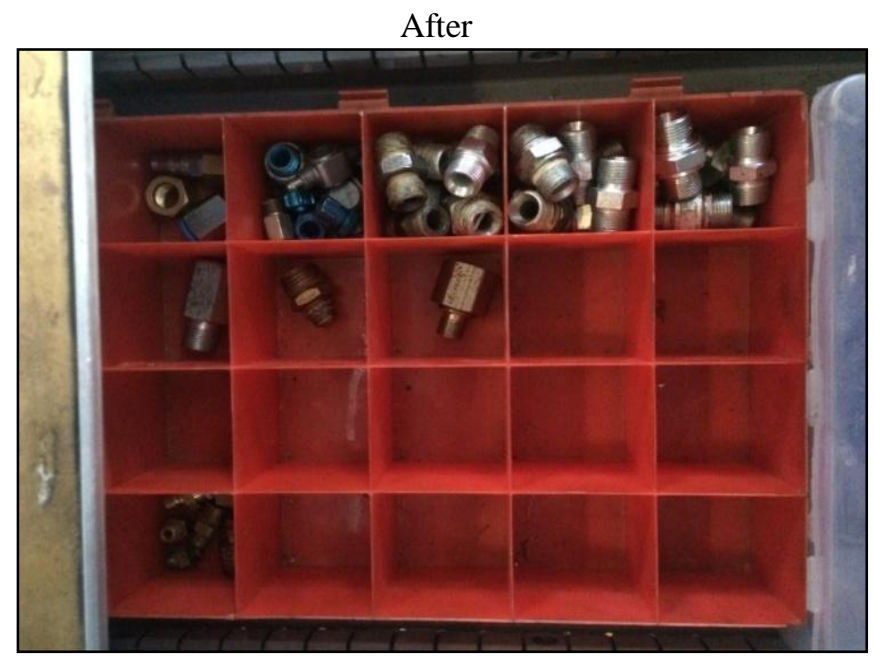

Fig -19: Fastener drawer

All the fasteners in the drawer were allocated separate space to reduce the time in searching for them.

\subsubsection{Main Assembly (Zone 4):}

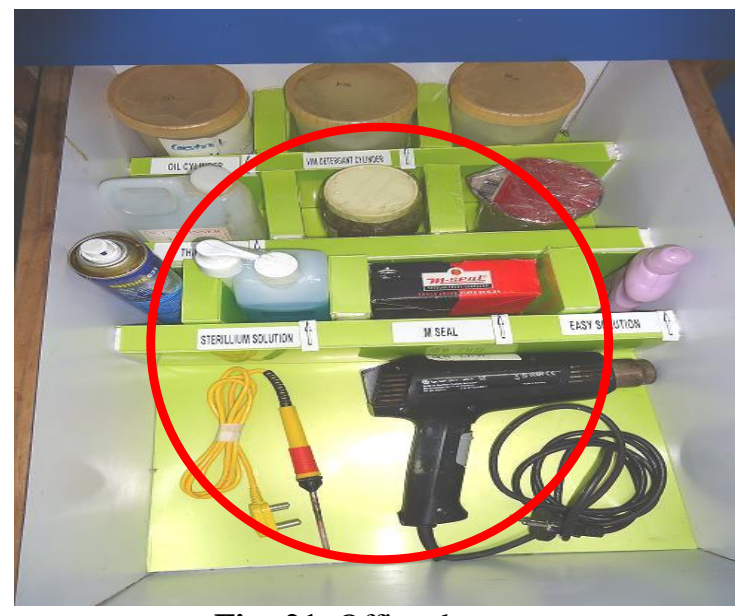

Fig -21: Office drawer

Shadow boards prepare by zone members from the rejected poly-propylene sheet for the appliances like hot gun, soldering gun etc. for easy finding.

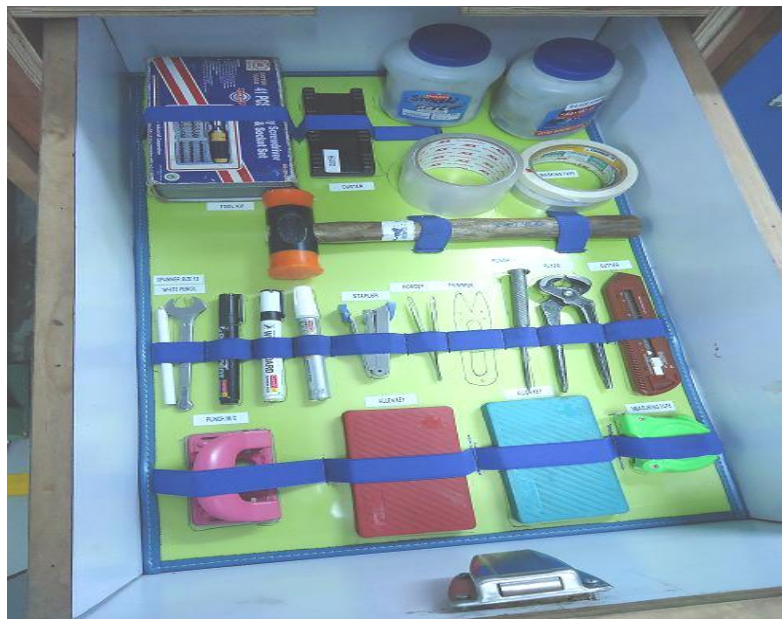

Fig -22: Office drawer
Shadow boards prepare by zone members from the rejected poly-propylene sheet for the hand tools like hammer, pliers, cutter etc. for easy finding.

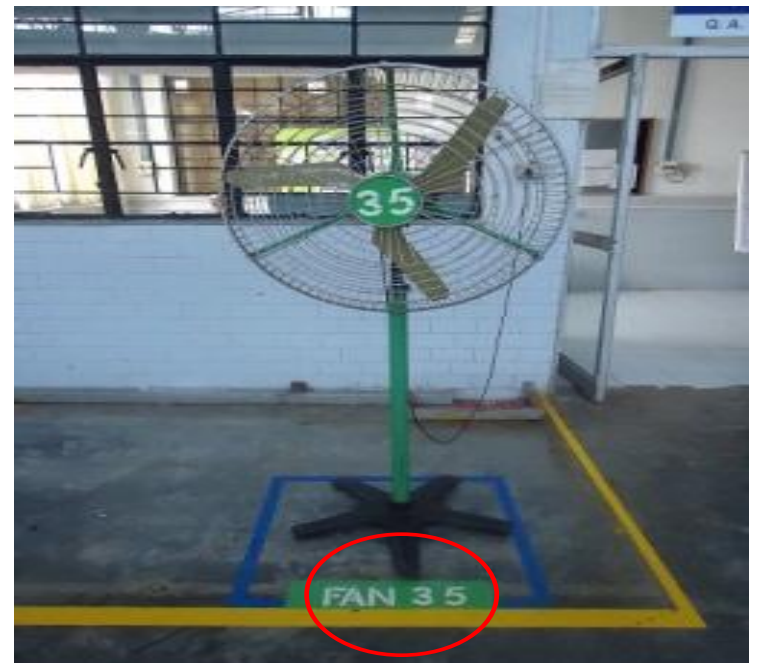

Fig -23: Fan location \& identity

Proper location for the fan with specific identity (fan number)
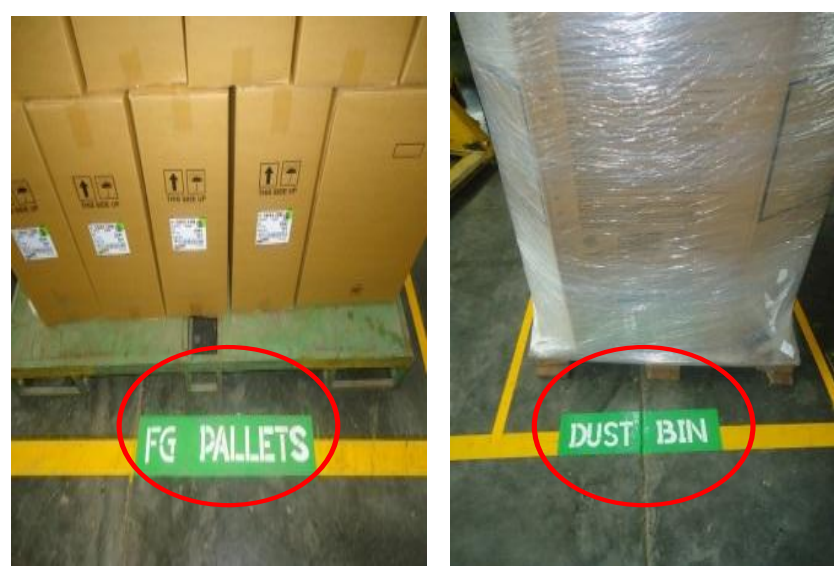

Fig -24: Finished goods pallet and dustbin location

Proper space is allotted for finished goods pallet and dustbin.

\subsubsection{BSR/RM Stores (Zone 3):}

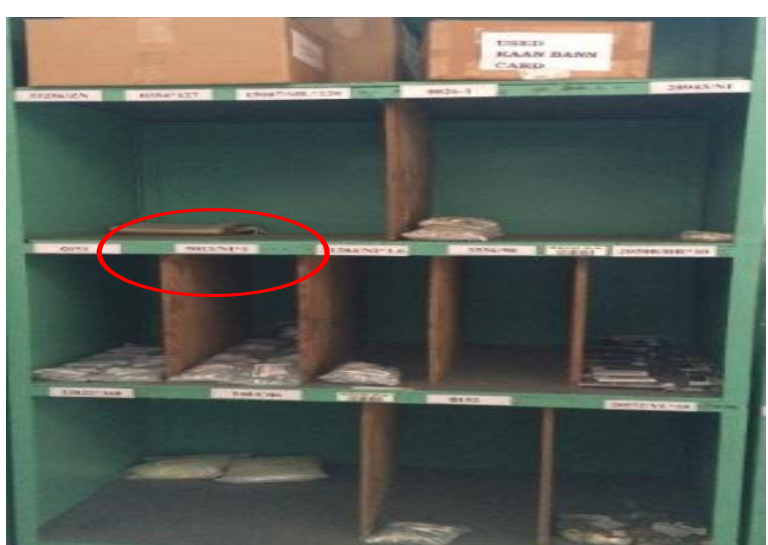

Fig -25: RM stores rack 
Proper place and identification given for raw material storage in the racks

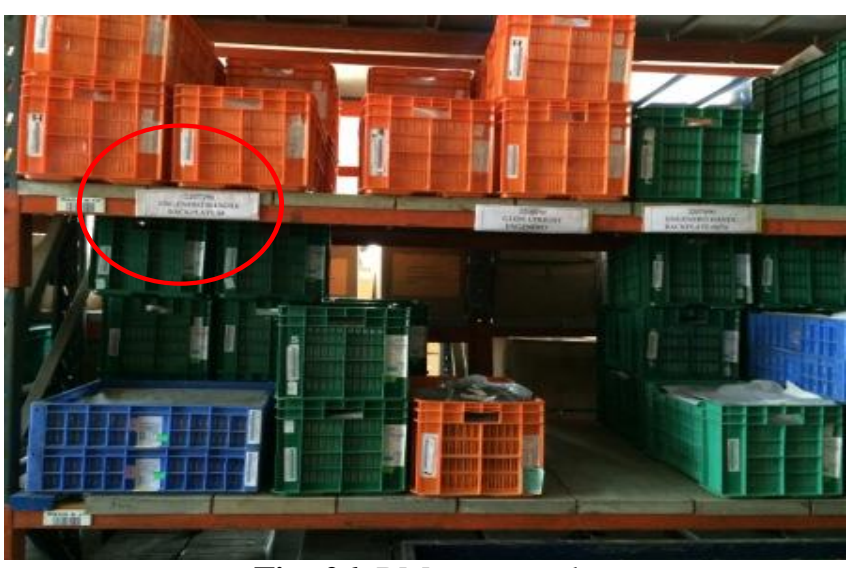

Fig -26: RM stores rack

Proper place and identification given for raw material carats in the storage racks

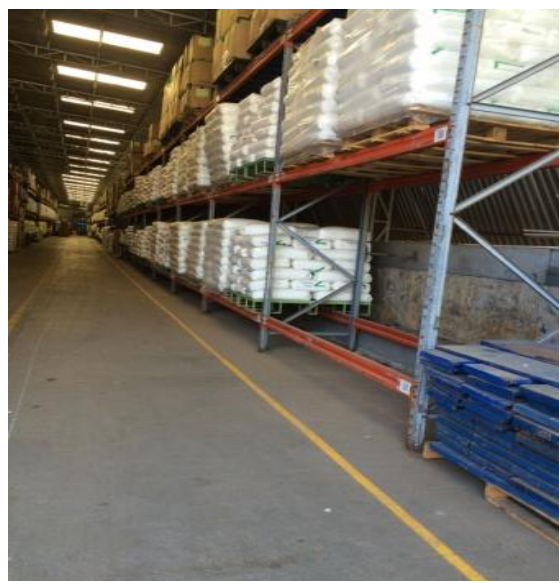

Fig -27: RM stores rack

Fixed location and identification given for storage of master batch and well defined gangway can be observed.

\subsection{Seiso (Shine-3S):}

Shine aims for keeping cleanliness at workplaces, workstations, offices, stores, outlet, passage ways, gangways, etc. in the organization.

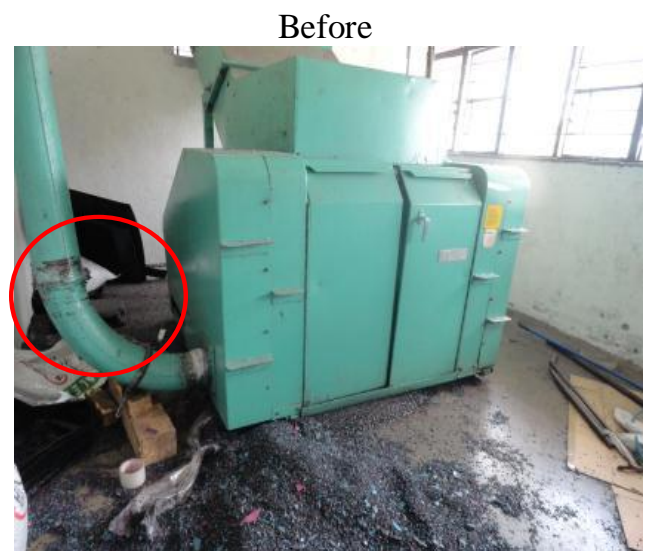

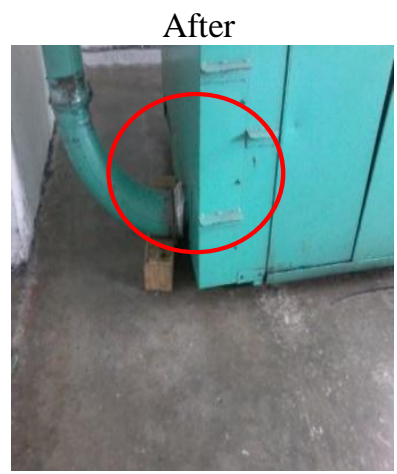

Fig -28: Grinding room

Cleaned workplace at the grinding room

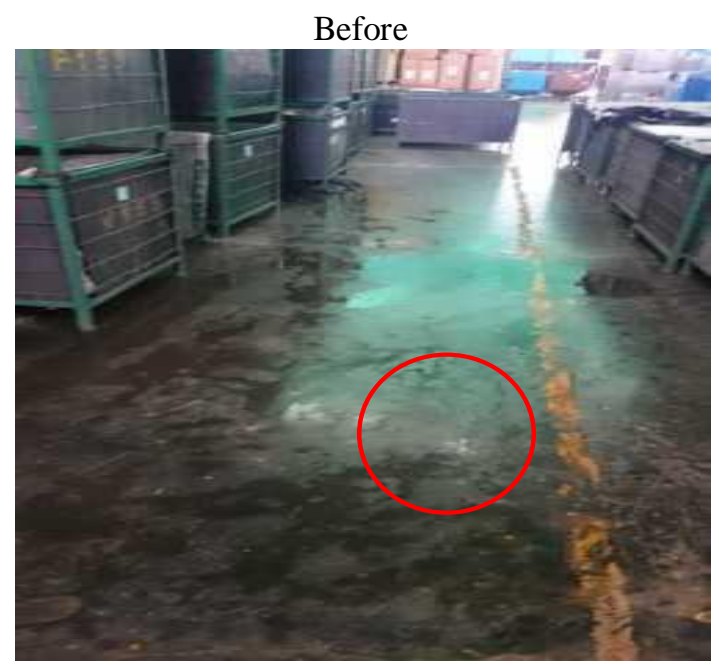

After

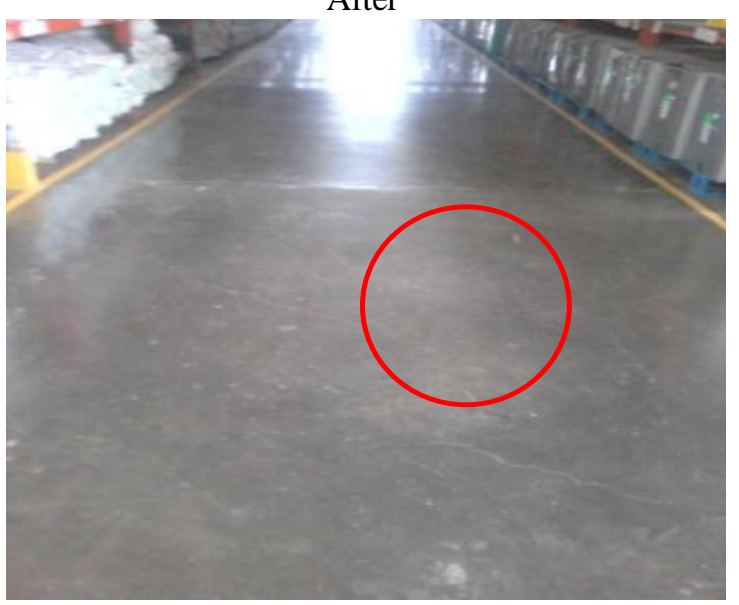

Fig -29: RM stores gangway 
Cleaned and properly marked gangway.
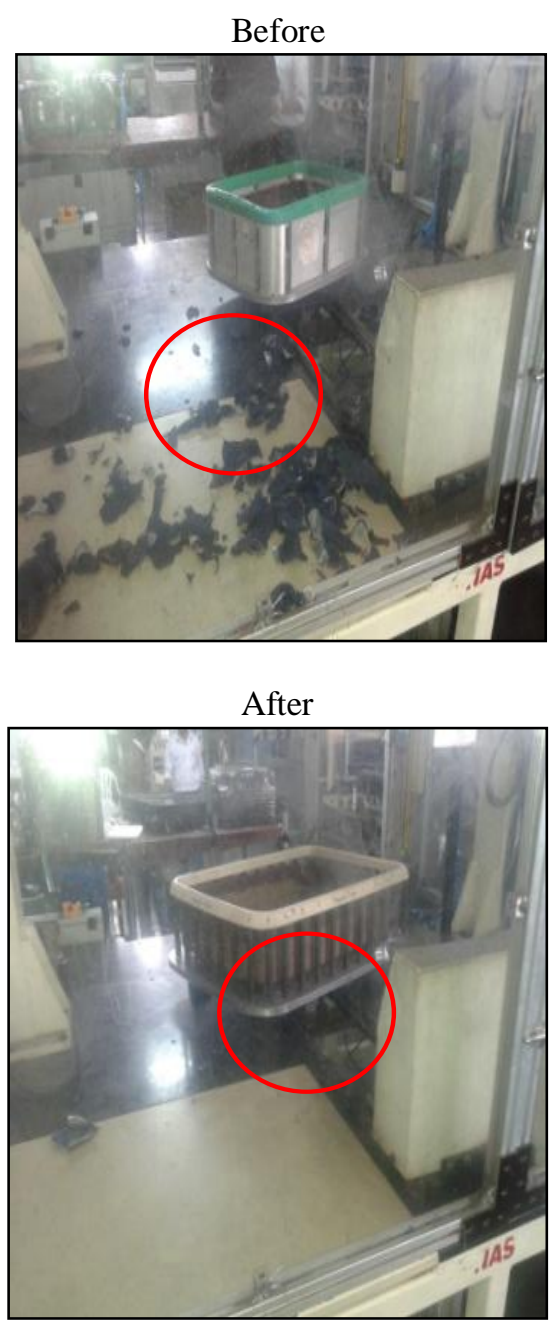

Fig -30: Inside area of cutting machine

Proper cleaning at the excess shell portion cutting machine

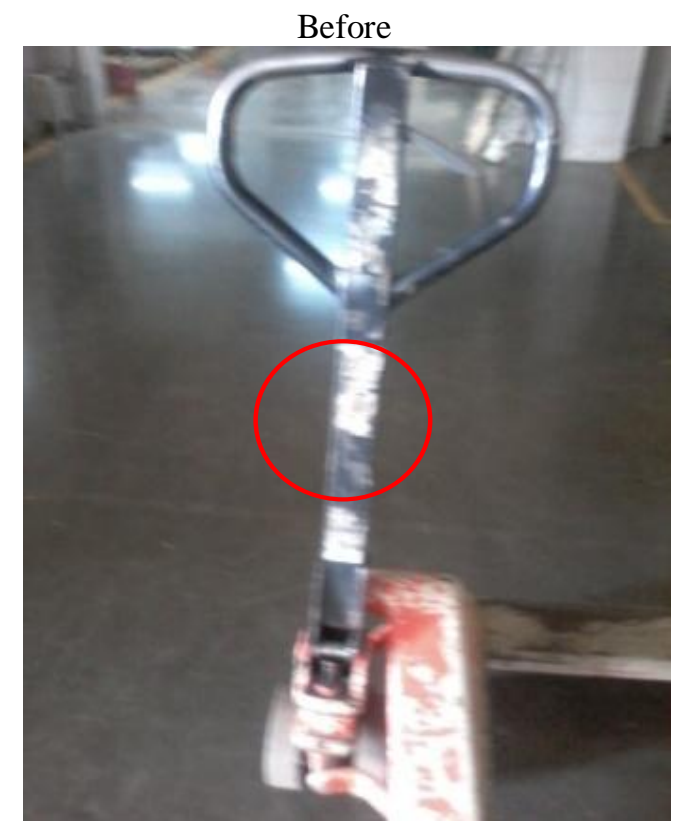

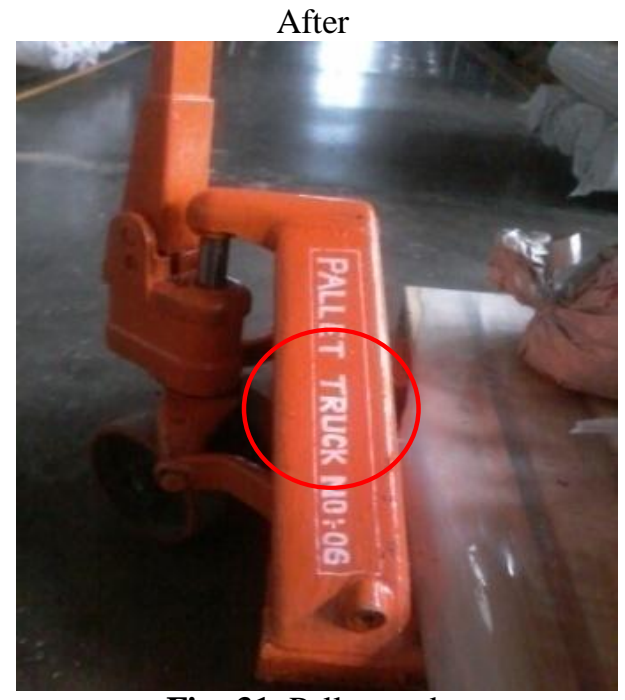

Fig -31: Pallet trucks

Pallet trucks are painted for the purpose of good look (i.e. shine).

\subsection{Seiketsu (Standardize):}

To strictly follow the first ' $3 \mathrm{~S}$ ' in the daily routine, the $4^{\text {th }}$ ' $\mathrm{S}$ ' i.e. Standardize is used. Standardize aims for preparation of standard methods to continue to follow the first ' $3 \mathrm{~S}$ ' effectively in the organization [2].

Thus to standardize, following activities were taken into consideration:

$>\mathrm{We}$ have prepared the standard operating procedures (i.e. SOP's) for machines as well as for assembly of luggage bag for workers in English and in their local language also. This is just to avoid mistakes which leads to rejection of final product.

$>$ We have maintained a red tag register in which we kept record of all the red tags for our reference. In daily routine, if workers notice unwanted thing at the workplace then a red tag is paste on it and decisions (to scrap or else) is taken. We used to collect that tags after every 8 days, then after 15 days, then after 1 month and maintained the record of it. Thus from the record we found out that the number of red tags decreased day by day (i.e. unwanted things vanished from the workplace).

$>$ We have made standard operating procedures for photocopy machine because previously 15-20 pages were being wasted on each photocopy machine per day.

$>$ We also defined the standard way of stacking/storing of the material which saves the cost of storage.

$>$ We also made the habit to conduct ' $5 \mathrm{~S}$ ' meetings and maintained the attendance record of each member. 


\subsection{Shitsuke (Sustain):}

Sustain aims for maintaining the implemented ' $5 \mathrm{~S}$ ' system effectively. Thus in short, sustain defines the discipline for employees to strictly follow the implemented ' $5 \mathrm{~S}$ ' in the organization to obtained the required result [2].

For sustaining the ' $5 \mathrm{~S}$ ' technique effectively and to strictly adhere to it in the organization, internal audits as well as surprise audits are conducted periodically.

\section{RESULT}

1. Productivity increased due to well defined space and systematic arrangement at the workplace

2. Time saving in searching for tools, raw material required for production due to standard storage system with proper identification. As a result of saving in time, productivity increased.

3. Tremendous cost required for the inventory of unwanted material is drastically reduced.

4. Availability of more space for raw material storage, bin storage and finished goods storage. Also clear and well defined gangway for movement is achieved.

5. Morale of the workers increased due to proper workplace management.

6. Equal participation of officers, staff and workers motivates them.

\section{CONCLUSION}

The paper aims for demonstrating the detailed implementation of ' $5 \mathrm{~S}$ ' in the organization which resulted in:

$>$ Proper workplace management for better use of working area.

$>$ Time saving in searching for tools and materials due to proper location and identification.

$>$ Huge cost saving from waste and unwanted materials.

$>$ Increased morale of the workers due to enhancement of working environment.

It is relatively a simple technique which can be easily applied in any organization and the results of it are rapidly visible.

\section{ACKNOWLEDGEMENTS}

With deep sense of gratitude we would like to thanks to all the people who have lit our path with their kind guidance. We are very grateful to these intellectuals who did their best to help during the case study.

It is our proud privilege to express deep sense of gratitude to Mr. Milnd Vaidya, Assistant Director and ' $5 \mathrm{~S}$ ' co-ordinator of Samsonite South Asia Pvt. Ltd., Gonde-Dumala, Nasik for his valuable guidance and kind permission for the completion of the case study. We are also thankful to the whole organization.

And lastly we thanks to our H.O.D and staff of Mechanical Department for their timely suggestion.

\section{REFERENCES}

[1] K. Ramesh, V. R. Muruganantham, N. R. Arunkumar, (2014) "5S Implementation Studies In Biomass Processing Unit", International Journal of Innovative Research in Science, Engineering and Technology, Vol. 3 special issue 4.

[2] S. B. Khedkar, R. D. Thakre, Y. V. Mahantare, Ravi Gondne, (2012) "Study of Implementing 5S Techniques in Plastic Moulding", International Journal of Modern Engineering Research, Vol. 2. Pp-3653-3656.

[3] J. Michalska, D. Szewieczek, (2007) "The 5S Methodology As a Tool For Improving The Organization", Journal of Achievement in Material And Manufacturing Engineering, Vol. 24, issue 2.

[4] P. M. Rojasra, M. N. Qureshi, (2013), "Performance Improvement Through 5S in Small Scale IndustryA case study", International journal of Modern Engineering Research, Vol. 3, pp-1654-1660.

[5] Shahryar Sorooshian, Maysam Salimi, Shanthi Bavani, Hasti Aminattaheri, (2012), "Case ReportExperience of $5 \mathrm{~S}$ Implementation", Journal of Applied Science Research, 8(7) 3855-3859.

[6] Lingareddy et al. , "5S As a Tool And Strategy For Improvising The Workplace", International Journal of Advanced Engineering Technology".

[7] Arash Ghodrati, Norzima Zulkifli,(2013), "The Impact of $5 \mathrm{~S}$ Implementation on Industrial Organizations", International Journal of Business and Management Invention, Vol. 2, Issue 3, pp-4349.

[8] Mohd Nizam Ab Rahman et al., (2010), "Imlementation of $5 \mathrm{~S}$ practices in The Manufacturing Companies: A case study", American Journal of Applied Science 7(8): 1182-1189.

[9] Noni Hartika Binti Juhari et al. , (2011), "Human Resource Management", Elixir Hum. Res. Mgmt 39(2011) 4836-4847.

\section{BIOGRAPHIES}

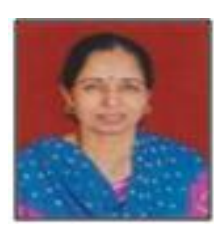

Mrs. Shraddha P. Deshpande, Assistant Professor (Mech. Dept.) B.E (Mech.), M.E. (Production), PhD (Pursuing from S.V.N.I.T).

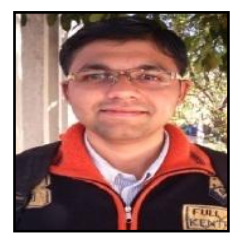

Vipul Vijay Damle, Pursuing Final Year in Bachelor of Mechanical Engineering degree from GES's R.H.S.C.O.E, Nasik, under the affiliation of University of Pune, Maharashtra, India.

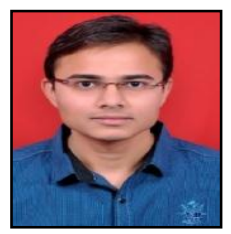

Merang Lalit Patel, Pursuing Final Year in Bachelor of Mechanical Engineering degree from GES's R.H.S.C.O.E, Nasik, under the affiliation of University of Pune, Maharashtra, India. 


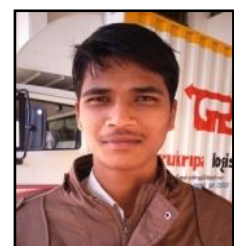

Akshay Bhaskar Kholamkar, Pursuing

Final Year in Bachelor of Mechanical

Engineering degree from GES's

R.H.S.C.O.E, Nasik, under the affiliation

of University of Pune, Maharashtra, India. 